\title{
Distinguishing post-kala-azar dermal leishmaniasis from leprosy: experience in the Sudan
}

\author{
A. M. EL HASSAN*, F. A. HASHIM*, \\ M. ABDULLAH†, E. E. ZIJLSTRA $\ddagger \&$ H. W. GHALIB \\ *Departments of Pathology and Physiology, Faculty of Medicine, \\ University of Khartoum; $\dagger$ Department of Dermatology, Khartoum \\ Teaching Hospital; $\ddagger$ Department of Infectious Diseases and Tropi- \\ cal Medicine, Academic Medical Centre, Amsterdam, The Nether- \\ lands; and §Department of Microbiology, College of Medicine, \\ University of Juba, Khartoum
}

\section{Accepted for publication 11 September 1992}

Summary In this study 4 patients were post-kala-azar dermal leishmaniasis (PKDL), whose lesions were similar to those of lepromatous and borderline leprosy, are described. In 2 patients there was no previous history of kala-azar but they were residents of an area of known endemic kala-azar. Lack of proper clinical and laboratory assessment was behind the failure to diagnose PKDL. Consequently the patients were treated with antileprosy drugs without proof of leprosy. The 3rd and 4th patients, though suspected clinically of leprosy, were correctly diagnosed as PKDL with adequate history, clinical assessment and appropriate laboratory investigations.

The salient points in distinguishing PKDL from leprosy are described and discussed.

\section{Introduction}

Post-kala-azar dermal leishmaniasis (PKDL) is characterized by the development of macules, papules, nodules or infiltrative plaques in the skin, usually following treated kala-azar. In some patients there is no past history of kala-azar. ${ }^{1,2}$ The condition is most frequent in India where it develops 1-5 years after the apparent cure of kala-azar. ${ }^{3,4}$ PKDL also occurs in the Sudan ${ }^{2,5}$ and Kenya. ${ }^{6}$ Unlike the Indian form, African PKDL is less frequent and develops during or shortly after treatment of Kala-azar. ${ }^{6}$

Clinically the nodules and hypopigmented macules may be confused with leprosy, as may the pathology, particularly when the recently-described neuritis of the cutaneous nerves is present in the PKDL lesion ${ }^{7}$ or when there is an epithelioid granuloma in which the parasites cannot be found.

In this paper we describe patients with PKDL who were misdiagnosed or who could have been misdiagnosed as leprosy sufferers because their symptoms strikingly resembled 
various forms of leprosy. Distinguishing features between PKDL and leprosy are described.

\section{Case reports}

The first patient was an Ethiopian refugee who reported with 2-year-old skin lesions on the face. At the onset of his illness, 5 years before, he had been diagnosed elsewhere as having leprosy on clinical grounds and was treated for 1 year with dapsone and rifampicin without improvement.

A skin biopsy was then performed. It showed a mononuclear cell infiltrate consisting of lymphocytes, plasma cells and macrophages. No leishmainia parasites were found but the pathology was considered to be suggestive of leishmaniasis.

The patient was consequently treated with sodium stibogluconate (Pentostam, Wellcome Laboratories, U.K.) for 2 months. The lesions disappeared but recurred 1 year later and have persisted ever since. On physical examination the only abnormality was found in facial skin. This showed nodules and infiltrative plaques over the chin, the left cheek, the nose and the eyebrows.

Peripheral nerves were normal and sensations were intact. A slit smear was negative for leishmania and acid-fast bacilli. A biopsy showed a chronic inflammatory reaction

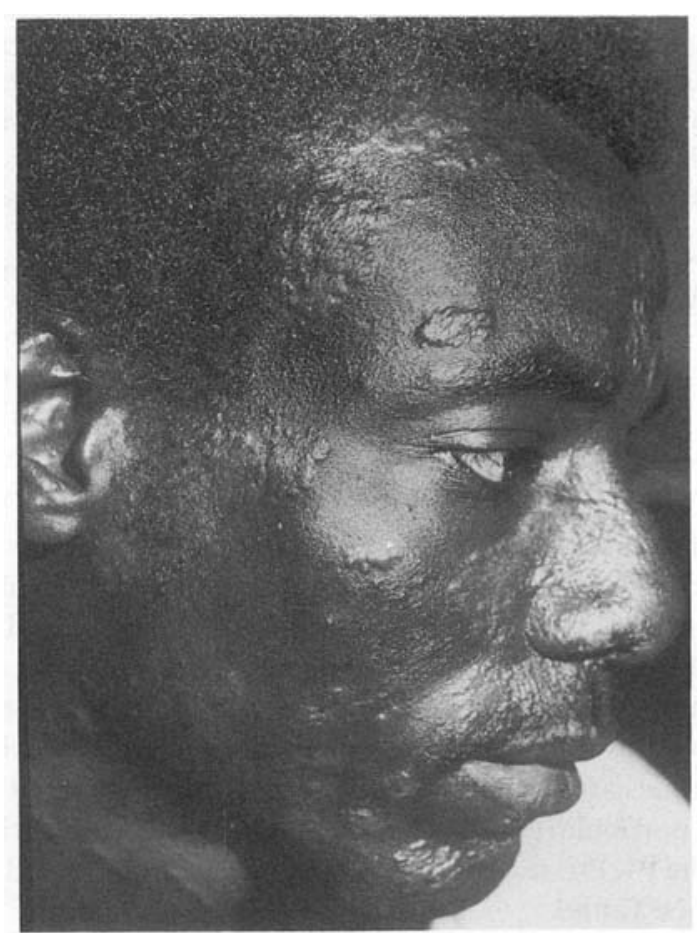

Figure 1. Patient number 2 showing hypopigmented and papular lesions over the face and neck. Some of the lesions are annular, have a hypopigmented centre, and raised papular margin. 


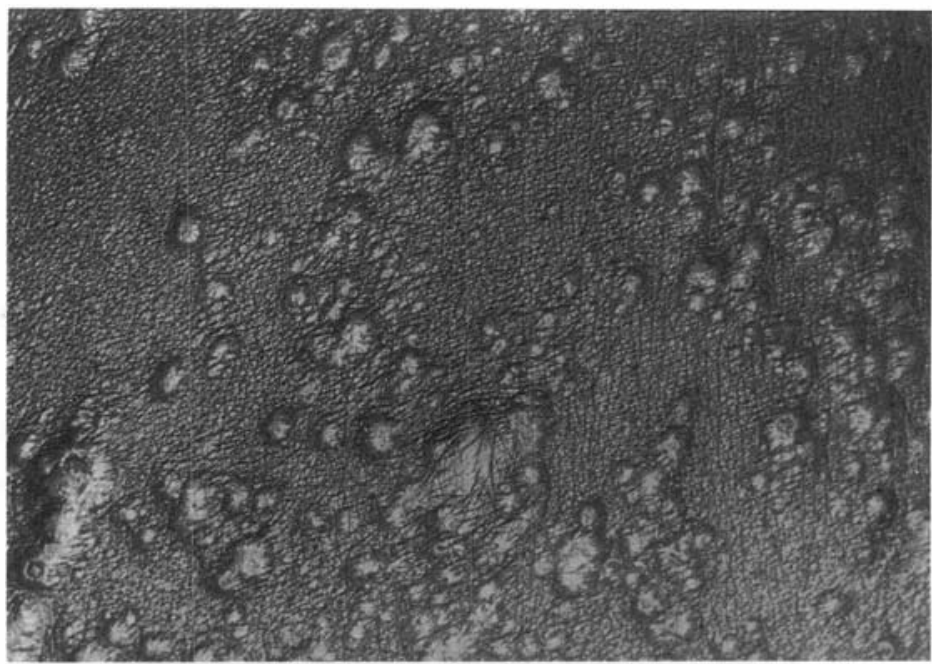

Figure 2. Patient number 3 showing nodules and infiltrative plaques in the back.

consisting of lymphocytes, plasma cells and macrophages. No leishmania parasites were detected. The patient was treated with Pentostam at a dose of $20 \mathrm{mg} / \mathrm{kg}$ daily for 3 months. Allopurinol at a dose of $20 \mathrm{mg} / \mathrm{kg}$ per day was also given at the same time. The lesions completely subsided and the patient remained well at 3 months follow up.

The second patient was a 24-year-old male from a known area of endemic kala-azar in the Sudan. He reported with a 10-year history of a skin rash involving the face, trunk, neck and limbs. He had no history of kala-azar. The patient had been on antileprosy treatment in another hospital for the previous 5 years without improvement.

The lesions were maculopapular and symmetrical. In some areas, particularly over the face, some of the lesions were annular with a coppery depigmented macule in the centre and papules at the margins (Figure 1). Peripheral nerves were normal and skin sensations were intact. A slit smear showed leishmania parasites and therewere no acid-fast bacilli. A direct agglutination test for serum antibodies against leishmania (DAT) was positive. ${ }^{8}$ The patient was treated with IV Pentostam at a dose of $20 \mathrm{mg} / \mathrm{kg}$ daily for 30 days. The lesions healed completely and he remained well for 1 year, when he reported with a recurrence.

He was then treated with Pentostam and Allopurinol at the same dosage and for the same duration as the 1 st patient. His lesions cleared and he remained well at the 14-month follow-up.

The 3 rd patient was a 20 -year-old male who had kala-azar 5 years before reporting to us. He developed skin lesions on the face, ears, neck, upper limbs and trunk 1 month after treatment of the kala-azar. He was seen by a dermatologist, who made a provisional diagnosis of lepromatous leprosy. A biopsy, however, was diagnosed as tuberculoid leprosy by a pathologist.

Because of the discrepancy between the clinical and the pathological diagnosis the patient was referred for evaluation. Examination revealed symmetrical nodular lesions and plaques involving the skin of the extremities, face, neck and trunk (Figure 2). 


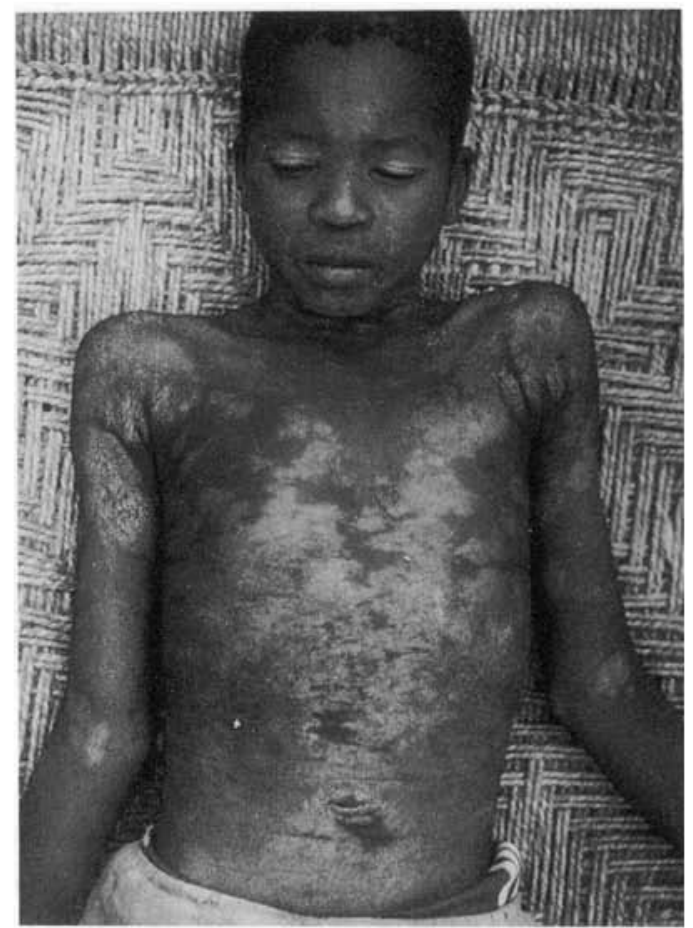

Figure 3. Patient number 4 before treatment with Pentostam showing extensive depigmented macules. Lesions in the face and limbs are symmetrical. Those over the trunk are confluent.

There was a marked lobulation of the ears. Peripheral nerves, motor power and reflexes were normal. Skin sensations were intact. A slit smear showed leishmania parasites. No acid-fast bacilli were found. A skin biopsy showed discrete epithelioid granulomas, lymphocytes and plasma cells. DAT was positive. The patient was treated with IV Pentostam at $20 \mathrm{mg} / \mathrm{kg}$ daily for 30 days. His lesions regressed markedly. After 6 months he was readmitted with a recurrence of lesions. He was treated with Pentostam and allopurinol, as described above. His lesions regressed but he was left with scars on the neck.

The 4th patient was discovered during a survey for kala-azar in a small village in the Eastern Sudan, near the border with Ethiopia. He was a 12-year-old male who had been treated for kala-azar when 8 years old. He developed a skin rash 10 days after the kalaazar treatment. He received no further treatment and the lesions gradually became worse. Examination showed macular and papular lesions on the face, upper limbs, neck and trunk. The lesions on the face and back were macules with a coppery appearance, and were symmetrical.

Over the chest and abdomen the depigmented areas were large and confluent (Figure 3 ). Over the shoulders and neck the lesions were maculopapular. Peripheral nerves and skin sensations were normal. DAT was positive. A slit smear showed leishmania parasites and there were no acid-fast bacilli. The patient was treated by a medical assistant in the village with Pentostam at a dose of $10 \mathrm{mg} / \mathrm{kg}$ daily for 15 days. 
At follow-up 1 year later the lesions had improved markedly but the hypopigmentation did not disappear completely. Because the treatment given was considered inadequate the patient was given another course of Pentostam of $10 \mathrm{mg} / \mathrm{kg} /$ day for 30 days but was not seen again.

\section{Discussion}

The first 2 patients were misdiagnosed as having leprosy and received antileprosy treatment, without benefit. A possible reason why PKDL was not initially considered in the differential diagnosis was because the patients did not give a previous history of kalaazar. In the Sudan most cases of PKDL follow an attack of kala-azar but it may occasionally occur in the absence of a history of a clinically manifest kala-azar. ${ }^{1}$

The 1st patient was clinically diagnosed as lepromatous leprosy. Apart from the nodular lesions there were no other features of leprosy. A properly performed skin smear, which is always positive in lepromatous leprosy, would have been negative in this patient and therefore would have excluded that diagnosis. The original diagnosis was made in a ref ugee camp by an expatriate physician who perhaps had little experience of the endemic diseases of the area.

It was only after the patient failed to respond to antileprosy treatment that the possibility of leishmaniasis was entertained. Leishmania parasites were neither found in the 1st biopsy nor in the one performed in our hospital. This is not surprising since parasites are sometimes few in number and cannot be identified in the section. ${ }^{9}$ In such cases culture, animal inoculation, or a polymerase chain reaction with appropriate primers may be helpful.

Clinically in this patient, diffuse cutaneous leishmaniasis, which occurs in Ethiopia, is an important differential diagnosis. Pathologically, however, this can be ruled out as leishmania parasites are numerous in diffuse cutaneous leishmansis and lymphocytes are scanty. ${ }^{10}$ These features were absent in the present case.

The second patient simulated borderline leprosy. In the latter condition there may be a few or several asymmetrical hypopigmented erythematous or coppery, partly welldefined patches. ${ }^{11}$ Annular and punched out lesions are characteristic. Our patient had annular lesions, papules and coppery macules. The lesions were possibly too symmetrical for borderline leprosy. A slit smear, which is usually positive for Mycobacterium leprae in borderline leprosy, was not done when the initial diagnosis was made, and biopsy was not performed. The patient was referred for evaluation only when the antileprosy treatment had failed to improve or clear the lesions. Eventually a slit smear and biopsy showed leishmania parasites and the patient responded to antileishmanial therapy.

The clinical appearance of the 3rd patient was remarkably similar to lepromatous leprosy. The lesions were symmetrical nodules and plaques. However, other features of long-standing lepromatous leprosy, such as madarosis, nasal involvement, thickened nerves, trophic ulcers and impairment of sweating were lacking. The diagnosis of lepromatous leprosy was dismissed when the pathology showed epithelioid granulomas and no mycobacteria. The diagnosis of PKDL was made on the demonstration of leishmania parasites in smears and the past history of kala-azar.

The 4th patient could easily have been mistaken for borderline leprosy. Indeed, when his photographs were shown to a group of dermatologists with experience in leprosy, 
most favoured a clinical diagnosis of borderline leprosy. The demonstration of leishmania parasites, the previous history of kala-azar, the positive serology and the marked improvement following antileishmanial therapy proved the leishmanial aetiology of the disease.

In 3 of the patients in whom serology was done, antibodies against leishmania were found-El Hassan et al. have already demonstrated that such antibodies are not found in the various forms of leprosy. ${ }^{1}$

\section{Acknowledgment}

We thank the Medical Illustrations Unit, the Faculty of Medicine, University of Khartoum for the photographs and Miss Nashwa El Hassan for typing the manuscript.

\section{References}

1 El Hassan AM, Ghalib HW, Zijlstra E, El Toum IA, Ali MS, Ahmed HMA. Post-kala-azar dermal leishmaniasis in the absence of visceral leishmaniasis. Lancet, 1990; 336: 750.

2 El Hassan AM, Ghalib HW, Zijlstra E, El Toum IA, Satti M, Ali MS, Ali HMA. Post-kala-azar dermal leishmaniasis in the Sudan: clinical features, pathology and treatment. Trans Roy Soc Trop Med Hyg, 1992; 86: $245-248$.

3 Napier LE, Das Gupta CR. A clinical study of post-kala-azar dermal Leishmaniasis. Ind Med Gaz, 1930; 65: 249-257.

4 Thakur CP. Epidemiological, clinical and therapeutic features of Bihar Kala-azar (including post-kala-azar dermal leishmaniasis) Trans Roy Soc Trop Med Hyg 1984; 78: 391-398.

${ }^{5}$ Kirk R, Satti MH. Studies in Leishmaniasis in the Anglo-Egyptian Sudan. IV. A punctate rash in treated cases. Trans Roy Soc Trop Med Hyg, 1940; 34: 213-6.

${ }^{6}$ Rees PH, Kager PA. Visceral Leishmaniasis and Post-kala-azar dermal leishmaniasis. In: The Leishmaniasis in Biology and Medicine, vol 2. Peters, W., Killick-Kendrik, R. (Eds). London: Academic Press, 1987, pp. 583-615.

7 El Hassan AM, Ali MS, Zijlstra E, El Toum IA, Ghalib HW, Ahmed HMA. Post-kala-azar dermal leishmaniasis in the Sudan: peripheral neural involvement. Int $J$ Dermatol, 1992; 31: 400-403.

${ }^{8}$ El Harith AE, Kolk AHJ, Kager PA et al. A simple and economic direct agglutinination test for serodiagnosis and sero-epidemiological studies of visceral leishmaniasis. Trans Roy Soc Trop Med Hyg, 1986; 80: 583-587.

9 Ramesh V, Saxena Uma, Misra RS, Mukherjee A. Post-kala-azar dermal leishmaniasis: a case report strikingly resembling lepromatous leprosy. Lepr Rev, 1991; 62: 217-221.

10 Bryceson ADM. Diffuse cutaneous leishmaniasis in Ethiopia. The clinical and histological features of the disease. Trans Roy Soc Trop Med Hyg, 1969; 63: 708-737.

11 Thangaraj RH, Yawalker SJ. Clinical features. In: Leprosy for Medical Practitioners and Paramedical Workers. Basle, Switzerland: Ciba Geigy Limited, 1988, pp 27-41. 


\title{
Comment distinguer entre la leishmaniose cutanée post-kala-azar et la lèpre: expérience au Soudan
}

\author{
A. M. El Hassan, F. A. Hashim, M. Abdullah, E. E. Zijlstra et \\ H. W. Ghalib
}

Résumé Dans cette étude, nous décrivons 4 patients atteints de leishmaniose cutanée post-kala-azar (PKDL) dont les lésions étaient similaires à celles de cas de lèpre lépromateuse et borderline. Chez 2 patients il n'y avait pas d'histoire antérieure de kala-azar, mais ils habitaient une région où le kala-azar est reconnu comme endémique. Le manque d'un propre bilan clinique et de laboratoire est à la base de l'échec de diagnostic du PKDL. Les patients ont donc été traités avec des médicaments anti-lèpre sans preuve de lèpre. Chez les 3ème et 4ème patients, bien que le tableau clinique fasse suspecter la lèpre, un diagnostic correct de PKDL a été porté, appuyé sur l'histoire, le bilan clinique et les examens de laboratoires appropriés.

Les points qui ressortent dans le diagnostic différentiel entre PKDL et la lèpre sont décrits et discutés

\section{Distinguiendo entre leishmaniasis dérmica post-kala-azar y la lepra: la experiencia en el Sudán}

\author{
A. M. El Hassan, F. A. Hashim, M. Abdullah, E. E. Zijlstra y \\ H. W. Ghalib
}

Resumen En este estudio, se describen 4 pacientes con leishmaniasis dérmica post-kala-azar (PKDL) con lesiones similares a la lepra lepromatosa y a la lepra incierta. En 2 pacientes, no habían antecedentes de kalaazar, pero residian en una zona conocida por ser endémica al kala-azar. El fracaso del diagnóstico para PKDL se debió a una falta de una evaluación clínica y de laboratorio apropiada. Por consecuencia, los pacientes fueron tratados con drogas contra la lepra sin prueba de la presencia de la lepra. El 3er y 4o pacientes, aunque sospechados clínicamente de ser leprosos, fueron correctamente diagnosticados para PKDL mediante una evaluación adecuada histórica y clínica, e investigaciones adecuadas de laboratorio.

Se describen y discuten los puntos sobresalientes cuando se distingue el PKDL y la lepra. 